Click www.researchjournal.co.in/online/subdetail.html to purchase.

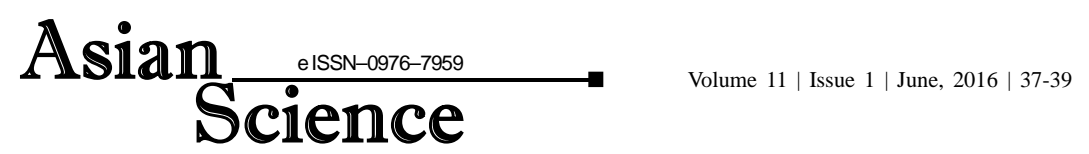

RESEARCH PAPER

\title{
Biochemical screening of kodo millets (Paspalum scrobiculatum var. L.) grown in region of Vindhyachal eastern U.P.
}

\author{
R.N. KEWAT, S.K.Z. RIZVI*, RAMESH P. SINGH, R.P. SINGH AND PRATIBHA SINGH \\ Department of Biochemistry, N.D. University of Agriculture and Technology, Kumarganj, FAIZABAD (U.P.) INDIA
}

\begin{abstract}
The present investigation was carried out in the laboratory Department of Biochemistry, N.D. University of Agriculture and Technology, Kumarganj, Faizabad during the year 2011-12 The various biochemical parameters such as protein content NDK-8 (11.12 \%), crude fibre content NDK-3 (3.90\%), Total mineral content NDK-3 (4.35\%), tryptophan content NDK-3 $(23 \mathrm{mg} / \mathrm{g})$, lysine content NDK-5 $(134 \mathrm{mg} / \mathrm{g})$, methionine content NDK-5 $(57 \mathrm{mg} / \mathrm{g})$, were also noticed in present investigation. Antinutritional factors such as Phytic acid content NDK-2 (147.05mg/100g) and Tannin content NDK-4 (119.28mg/100g).
\end{abstract}

Key Words : Biochemical, Screening, Kodo millets, Paspalum scrobiculatum var. L.

View point paper : Kewat, R.N., Rizvi, S.K.Z., Singh, Ramesh P., Singh, R.P. and Singh, Pratibha (2016). Biochemical screening of kodo millets (Paspalum scrobiculatum var. L.) grown in region of Vindhyachal eastern U.PAsian Sci., 11 (1): 37-39, DOI : 10.15740/HAS/AS/ 11.1/37-39.

\footnotetext{
* Author for correspondence S.K.Z. Rizvi, Department of Biochemistry, N.D. University of Agriculture and Technology, Kumarganj, FAIZABAD (U.P.) INDIA (Email: kulsoom.zehra786@gmail.com)
} 